\title{
Demand Patterns in France, Germany, and Belgium: Can We Explain the Differences?
}




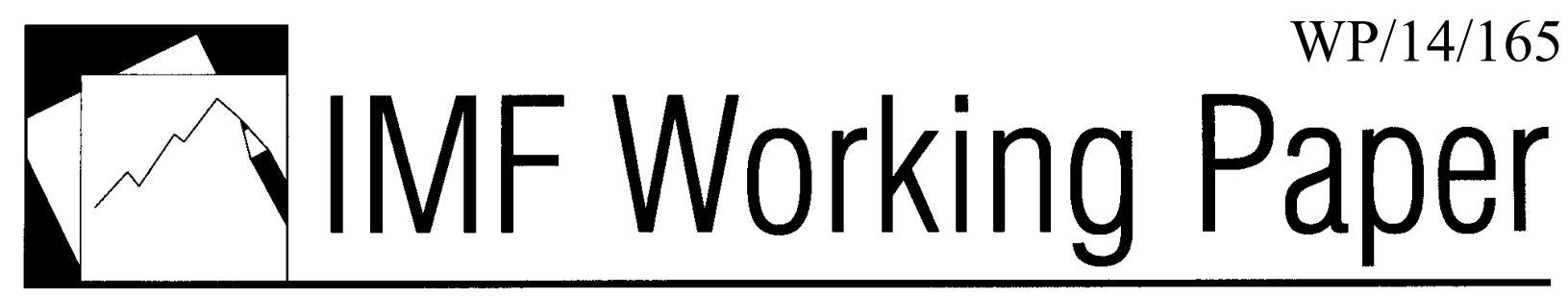

\section{Demand Patterns in France, Germany, and Belgium: Can We Explain the Differences?}

Igor Lebrun and Esther Pérez Ruiz 


\title{
IMF Working Paper
}

European Department

\section{Demand Patterns in France, Germany, and Belgium: Can We Explain the Differences?}

\author{
Prepared by Igor Lebrun and Esther Pérez Ruiz
}

September 2014

\begin{abstract}
The need to revive Euro area growth highlights the importance of the evolution of domestic and external demand in the core. This paper puts recent demand patterns in France, Germany, and Belgium into historical perspective. We find that, first, dynamics for private consumption, non-residential business investment, and exports since 2008 is dominated by conventional determinants, with no discernible structural break as a result of the crisis. Second, although country-specific factors matter in some cases, demand patterns in these countries are largely driven by common determinants. Third, developments in common fundamentals tend to dominate demand dynamics, coupled, in a few cases, with structurally different elasticities across countries. Fourth, short-term analysis suggests a role for confidence and uncertainty factors in explaining temporary deviations of these variables from long-term fundamentals.
\end{abstract}

\section{This Working Paper should not be reported as representing the views of the IMF.} The views expressed in this Working Paper are those of the author(s) and do not necessarily represent those of the IMF or IMF policy. Working Papers describe research in progress by the author(s) and are published to elicit comments and to further debate.

JEL Classification Numbers: E32, E62, E61, H20, H5, H60, E1

Keywords: growth, demand patterns, Germany, France, Belgium.

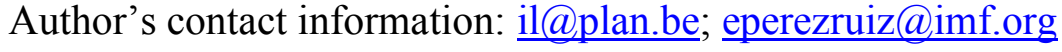




\section{Contents}

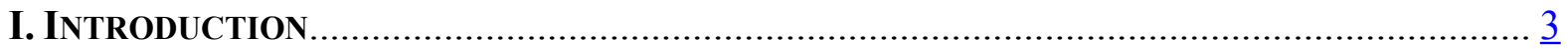

II. Demand Patterns in France, Germany, ANd Belgium .................................... 4

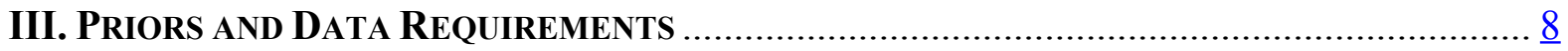

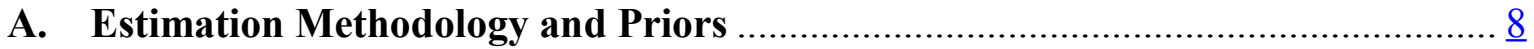

B. Data and Measurement Issues .............................................................. 10

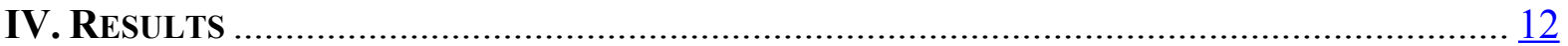

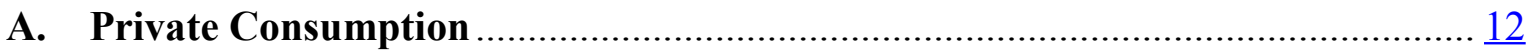

B. Non-residential Business Investment …….................................................. 16

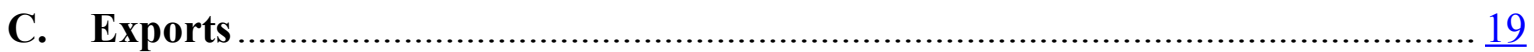

D. Demand Patterns in France, Germany, and Belgium: Are They Different?...... 21

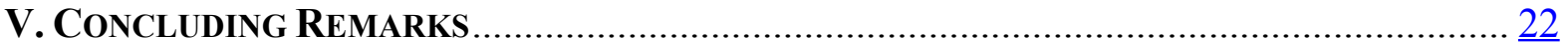

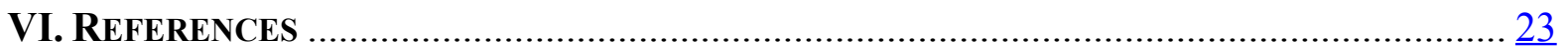




\section{INTRODUCTION ${ }^{1}$}

Since the mid-nineties, the French and German domestic and external demand have shown dissimilar patterns. Although strongly integrated to the German economy, Belgium has evolved much more like France. During the pre-crisis period, private consumption and nonresidential business investment were increasing at a steady pace in France and Belgium, while growth in domestic demand was much more subdued in Germany. In contrast, exports grew much faster in Germany than in its two Western neighbors. German exports recovered very strongly following the sharp contraction in 2009 , while they grew at a much slower pace in France and Belgium. By contrast, the gap in domestic demand between Germany on the one hand, and France and Belgium on the other, is narrowing as a result of the crisis.

In this paper we confront demand patterns since the mid-1990s for these three countries. We focus on two distinct questions. First, do consumption, investment, and exports in the three countries essentially respond to the same underlying, conventional determinants and have fundamentals changed as a result of the crisis? Second, what additional variables, particularly uncertainty, play a role to explain short term movements in consumption, investment, and exports? To this, we estimate error correction models for each country and each demand component. We compare the contributions from fundamentals to the relevant demand components and check on the equality of the long-term elasticities. We also use the results from the dynamic equation to explain temporary deviations of private consumption and nonresidential private investment from long-term fundamentals, with a particular focus on the role played by confidence and uncertainty.

The rest of the paper is organized as follows. Section II describes demand patterns and their main determinants in the three countries since the mid-1990s. Section III discusses the priors tested in the empirical analysis and the estimation methodology, as well as data and measurement issues. Section IV presents and comments the econometric results, including the contributions of the various factors to long-term demand patterns, the hypothesis of equality for long-run coefficients, and role of confidence and uncertainty in driving shortterm demand dynamics. Section V concludes.

\footnotetext{
${ }^{1}$ We thank Edward Gardner, Subir Lall, Jérôme Vandenbussche and colleagues from the National Bank of Belgium for helpful comments. We are grateful to Derek Mason for excellent research assistance and Eric Ruscher from the European Commission for guiding us through the uncertainty indicators.
} 


\section{Demand Patterns in France, Germany, ANd Belgium}

During the decade preceding the crisis Germany has on average grown more slowly than Belgium and France. However, since the start of the crisis, the German economy has performed much better, with the sharp contraction in 2009 being followed by a swift rebound in 2010. The 2009 GDP fall in France and Belgium was contained in comparison, but their subsequent performance has proven more muted, especially in France, where output levels have only recently reached pre-crisis levels. In parallel, Germany's employment performance has been impressive. While a decade ago Germany had the worst jobless rate of all three countries, today's unemployment rate of 5.1 percent is one of the lowest in Europe (10.1 and 8.5 in France and Belgium, respectively).

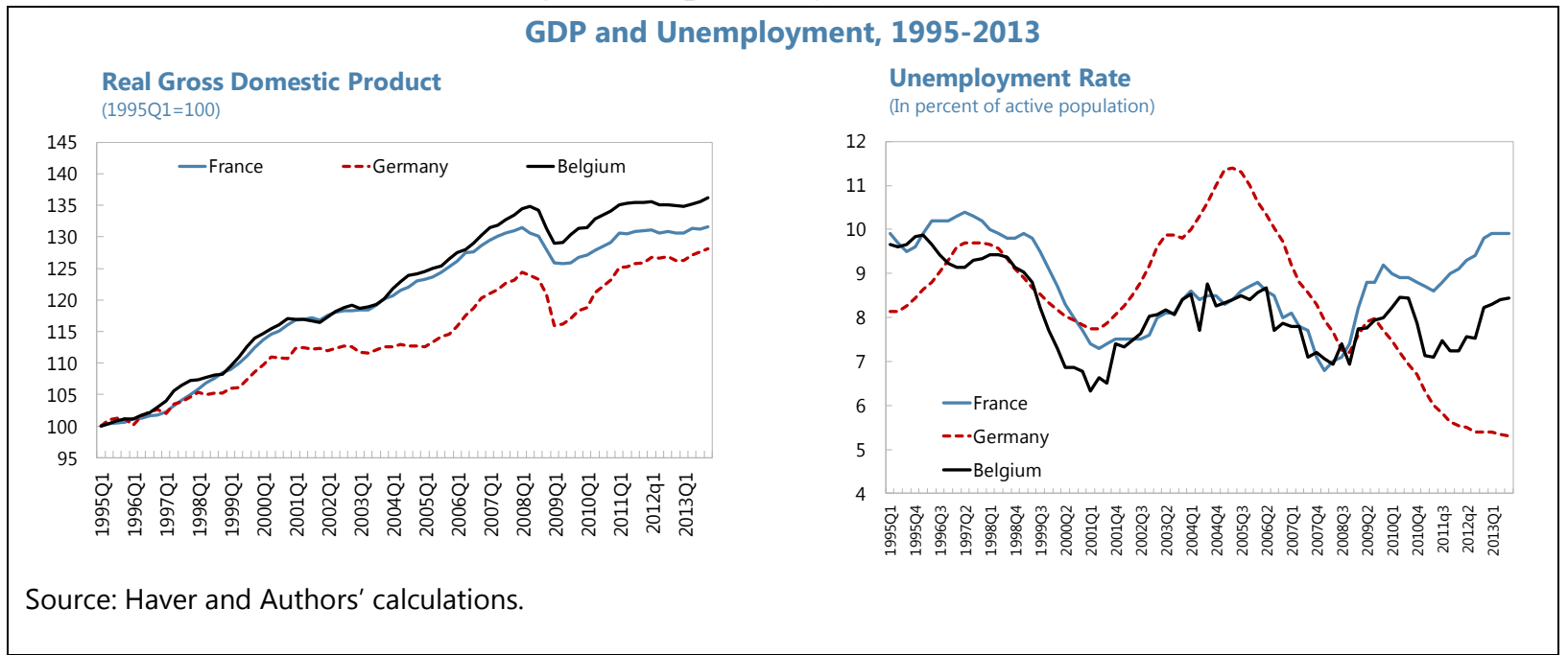

Almost half of Germany's growth over the past decade has come from net exports. At around 7 percent of GDP and rising (against around -2 percent in France and zero in Belgium), the (National Accounts) current account surplus is now more than three times as high as it was a decade ago, and one of the biggest relative to the size of the economy. German exports to fast growth emerging economies (mostly machine tools, chemicals, and cars) have been stronger than those of France and Belgium, aided by restrained wages and strong price competitiveness (Iwulska, 2012).

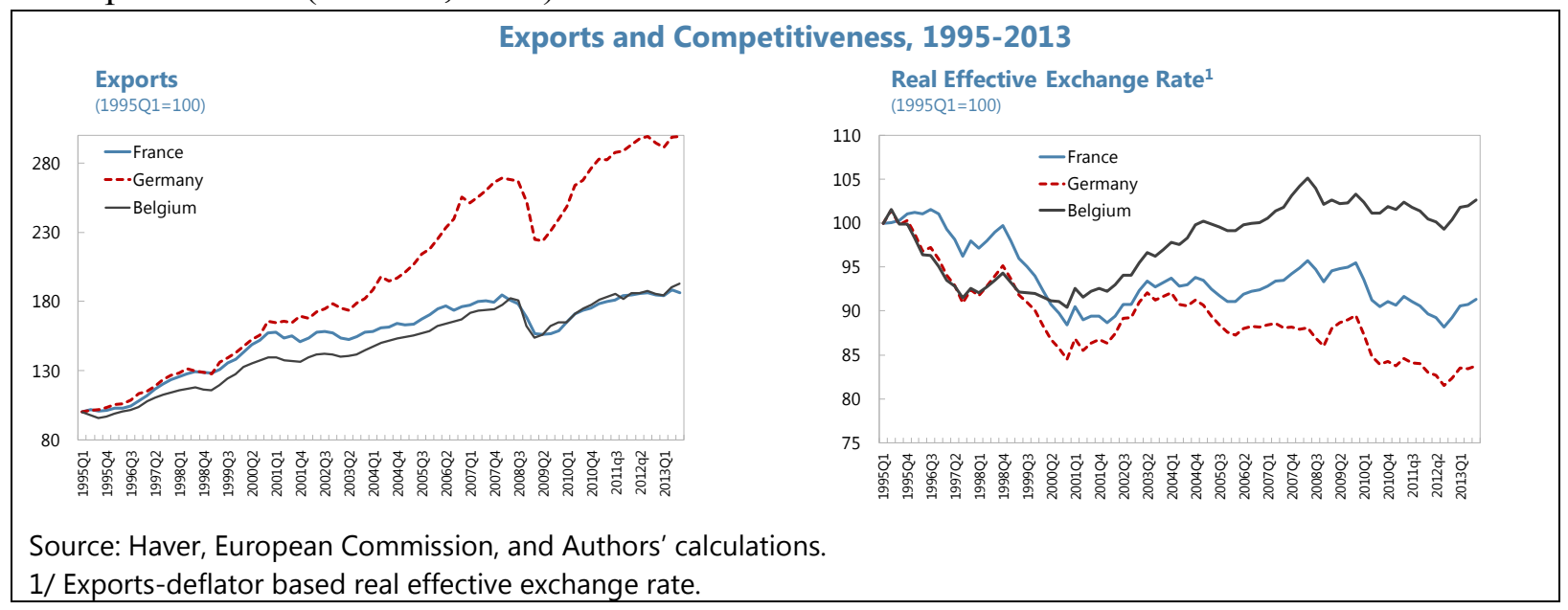


The flipside of Germany's export-driven growth is the weak growth of domestic demand. German investment as a share of GDP has fallen sharply from 22 percent in 2000 to 17 percent in 2012 (against 19 and 20 percent in France and Belgium, respectively). Public investment has been constrained by debt ceilings and firms have been cautious about capital spending, although this situation is rapidly changing at present. Non-residential business investment in France and Belgium has been more dynamic in comparison, despite profit margins growing lower than in Germany (Belgium) or even contracting (France).

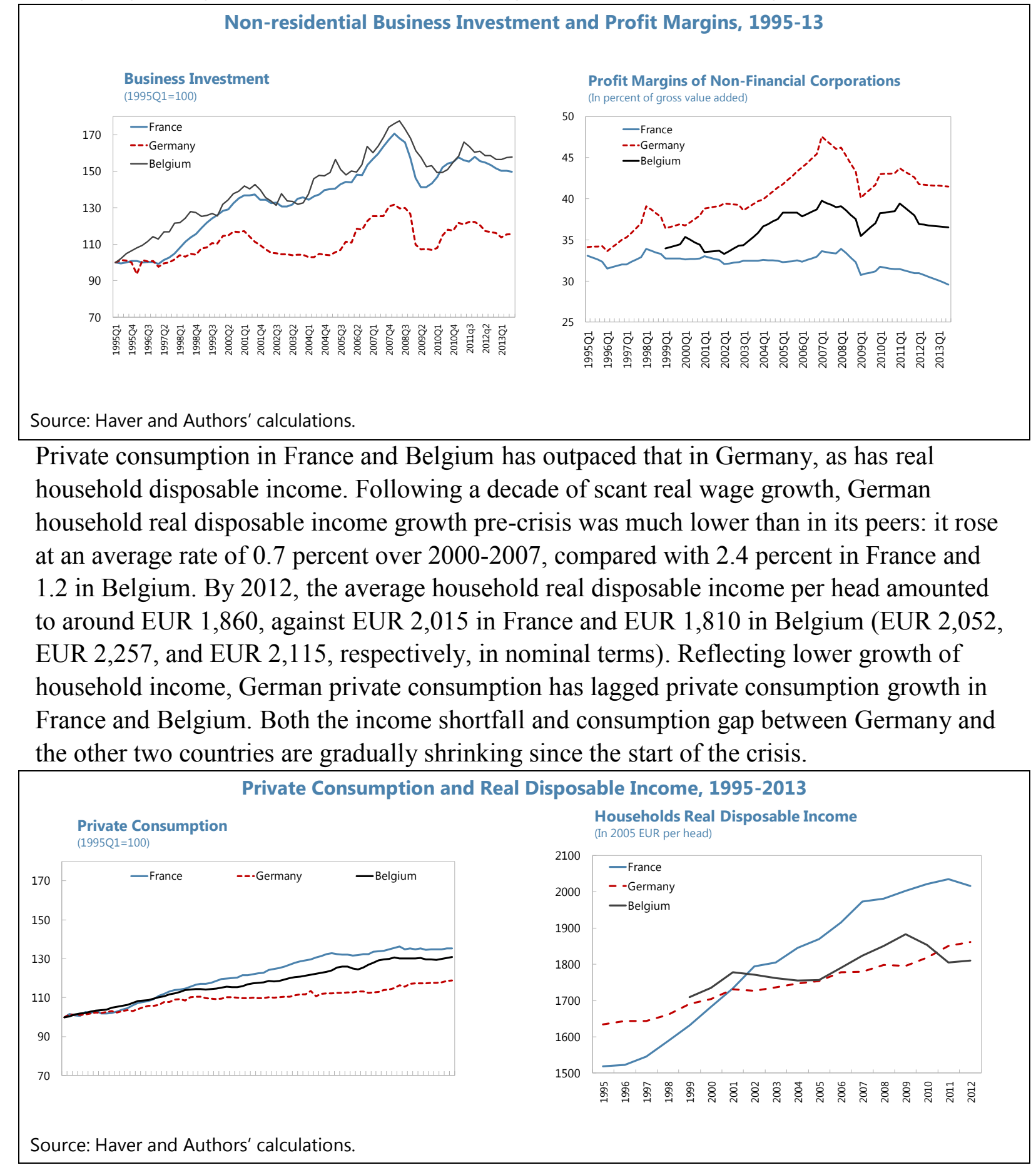


By income components, the contribution of labor compensation to nominal income growth was particularly weak in Germany pre-crisis, as rising unemployment, the effects of the Hartz IV labor reform (Krebs and Scheffel, 2013), and the threat of off-shoring production networks to neighboring countries (Dustmann and others, 2014) all contributed to wage restraint. Between 2000 and 2007, the contribution of labor compensation to households real disposable income growth averaged -0.3 ppts. against 1 ppts. in France, and 1.1 ppts. in Belgium. A rising tax burden and contributions to the social security system also weighed heavily on Germany household income, and, unlike in France, social benefits contributed little to lift households' purchasing power.

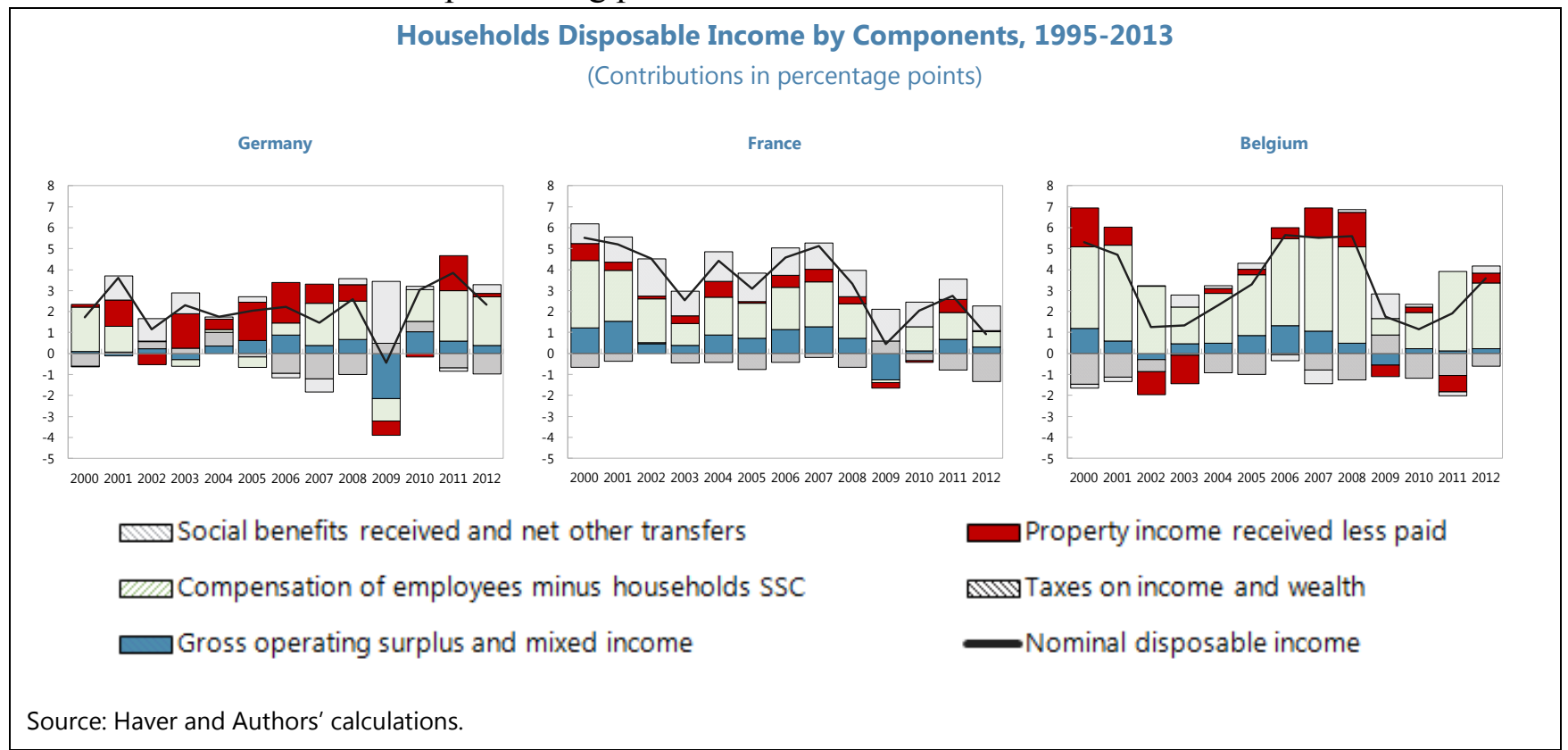

Besides long term fundamentals such as disposable income and profit margins discussed above, other factors may impact on private consumption and investment in the short term, in particular, households' and firms' perception about future economic conditions. Did economic expectations evolve differently in the countries during the crisis? Confidence and uncertainty indicators for both firms and households (Figure 1) suggest that:

Consumers' confidence fell sharply in 2008/09 in the three countries and uncertainty reached unprecedented levels. Thereafter, there has been a distinct pattern between Germany, where consumers' confidence and uncertainty have improved steadily since their record -lows in 2008/09, and France and Belgium, where households' confidence has continued to deteriorate and uncertainty has increased markedly.

Business confidence has followed a somewhat similar pattern in the three countries since 2008/09 while developments in uncertainty are less clear. Confidence is highly correlated across countries. After a major setback at the trough of the crisis, it bounced back to reach historical highs in early 2011, before declining again all through 2011/12. Confidence improved thereafter, but it remains low by historical comparison. Business uncertainty has abated considerably after the sharp increase registered in 2008, yet it remains unusually high. 
Figure 1. France, Germany, and Belgium: Confidence and Uncertainty Indicators, 1995-2013

Consumer Confidence

(balances of responses $1 /$ )

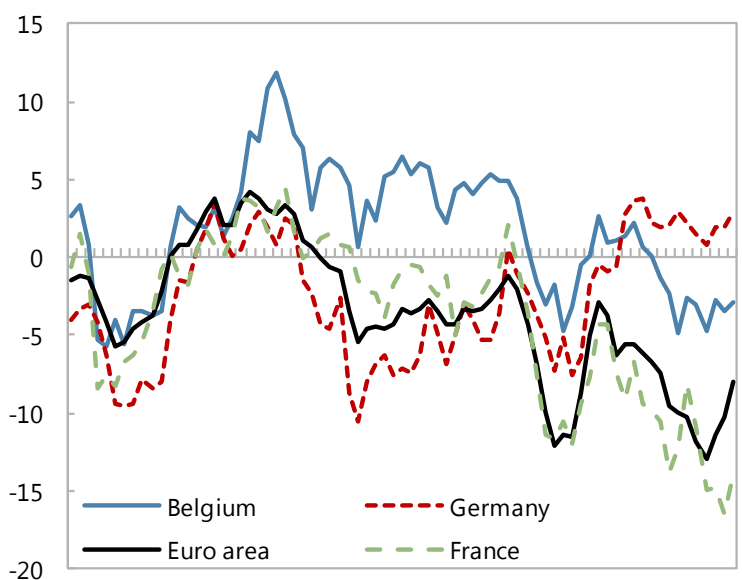

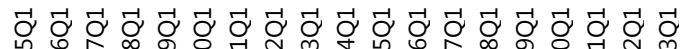

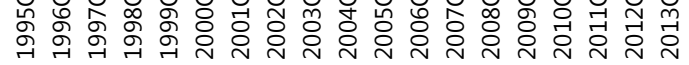

Consumer Uncertainty

(Index, normalized 2/)

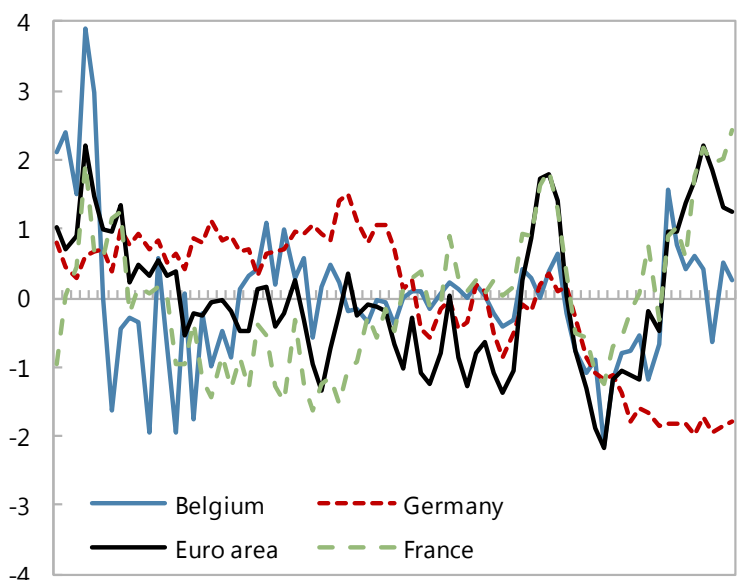

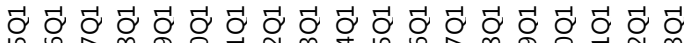

光 न
Business Confidence

(balances of responses $1 /$ )

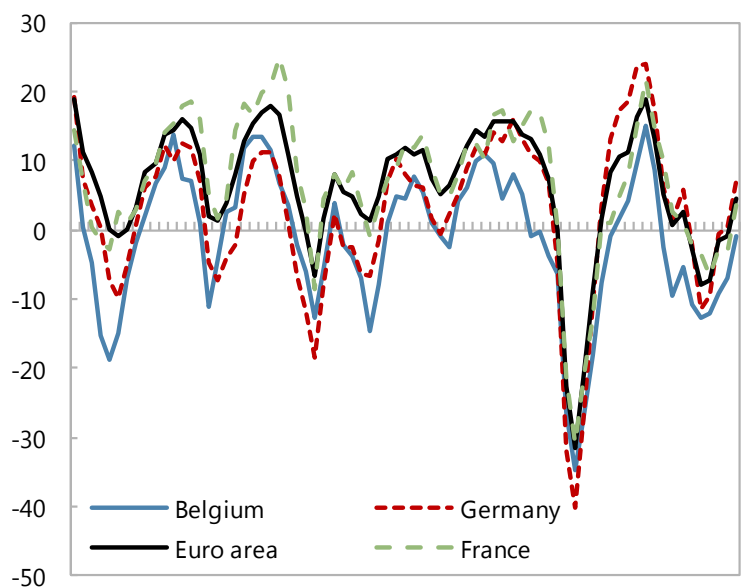

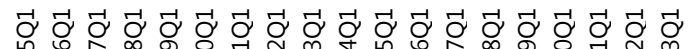

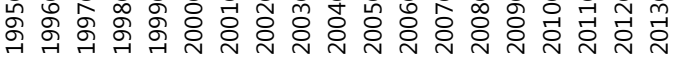

Business Uncertainty

(Index, normalized 2/)

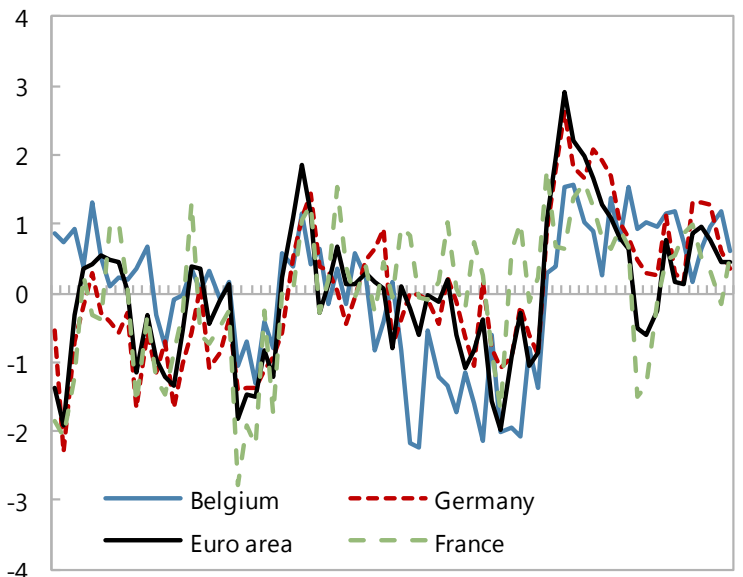

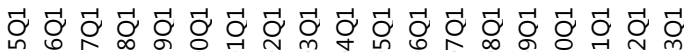
命

Source: European Commission Business and Consumer Surveys, and Authors' calculations.

1/ Balance of responses about future economic conditions. The two relevant questions are "how do you expect you expect the financial position of your household to change over the next 12 months"and "how do you expect your production to develop over the next three months?"See Section III.B for details.

2/ Dispersion of responses about future economic conditions as measured by expression (5), Section III.B. Index ranges from 0 (respondents fully agree on economic prospects) to $0.3 / 0.4$ (greatest divergence in expectations among households/firms). Questions addressed to consumers and businesses as in footnote $1 /$. 


\section{Priors ANd Data Requirements}

\section{A. Estimation Methodology and Priors}

We interpret the demand trends in France, Germany, and Belgium by means of co-integration models. We use quarterly data covering the period 1995Q1-2013Q3 to estimate long-term expressions for consumption, investment, and exports. All co-integration relationships are estimated using Fully Modified OLS (FMOLS) (Phillips and Moon, 1999; Pedroni, 2000, 2001; Kao and Chiang, 2000; Mark and Sul, 2003) which produces asymptotically unbiased, normally distributed coefficient estimates allowing for statistical inference testing. The cointegration relationship takes the form:

$$
Y_{t}=c+\alpha X_{t}+\varepsilon_{t}
$$

where $Y$ is the explained variable (consumption, investment, exports), $c$ is the constant of the regression, and $X$ is a vector of established fundamentals by economic theory. This comprises disposable income, net financial wealth, lending rates, and the unemployment rate for consumption; the value added of the private sector and a set of financial and financing conditions (profit margins, the real cost of capital, ${ }^{2}$ and leverage and credit rationing indicators) for investment; and an relative export prices and the world demand addressed to each country for exports.

The short-term, dynamic equation is estimated by OLS. It links changes in private consumption, non-residential business investment, and exports to changes in its long-term determinants; swings in firms' confidence and uncertainty about future economic conditions ${ }^{3}$; as well as deviations of the dependent variable from its long-term value (or error correction term). The dynamic relationship therefore takes the form:

$$
\Delta Y_{t}=\beta \Delta Y_{t-i}+\gamma \Delta X_{t-i}+\delta \Delta U_{t}+\lambda E C M_{t-1}+\varepsilon_{t}
$$

where $\Delta$ denotes first differences and $i=0,1,2, U$ stands for confidence and uncertainty indicators, and ECM represents the deviation of the dependent variable from its long-term value. We estimate by OLS two variants of this equation, excluding and including the confidence and uncertainty indicators presented in the previous section and discussed at length in section III.B.

The priors tested in Section IV are informed by mainstream macroeconomic theory (summarized in Table 1). According to Keynesian economics, consumer spending is influenced by the level of disposable income (Keynes, 1936). However, the so called

\footnotetext{
${ }^{2}$ See Section III.B for details on measurement.

${ }^{3}$ See Section III.B for details on measurement.
} 
"absolute income hypothesis" ignores the role of future income, which led to the development of the permanent income hypothesis (Modigliani and Brumberg, 1954 and Friedman, 1957) later adapted to a stochastic context by Hall (1978) ("martingale's hypothesis" under rational expectations). More recent theoretical approaches focus on microeconomic foundations (Romer, 2011). A constant relative risk aversion-based consumption approach postulates a relationship between consumption and the interest rate, which is negatively signed if substitution and income effects move in the same directions (debtors), but ambiguous if those effects move in opposite directions (creditors). The role of uncertainty in driving consumption was first formalized by Leland (1968), whereby strongly risk-averse consumers ${ }^{4}$ set aside a precautionary reserve to avoid future income fluctuations and retain a smooth consumption, especially in the face of incomplete insurance markets.

Genuine investment theory (i.e. the determination of an optimal pace of adjustment toward the desired level of capital stock) emerges with post-Keynesian basic accelerator models. Criticism that the speed of adjustment to the optimal capital stock was introduced ad hoc in these models led to the development of the literature on adjustment costs (Eisner and Strotz, 1963). The incorporation of adjustment costs to an otherwise standard firm's inter-temporal profit maximization problem allowed Jorgenson (1971) to obtain an optimal pace of adjustment for capital (i.e. an investment function), which related changes in investment to changes in output, taken to be the primary determinants of firms' expected profits (Tobin's q). Jorgenson's model also implied that firms invest up to the point where the rate of return on capital matches its opportunity cost, and, from there, the neoclassical model related investment to the real cost of capital, and, by extension, to firms' financial position and general credit conditions in the economy. Investment theory received an additional impulse in the 1980s and 1990s, thanks to the contributions from Bernanke (1983) and Pindyck (1991). These authors pointed to the role of uncertainty in driving investment decisions: elevated uncertainty increase the option value of deferring investment since it is difficult to reverse it once new capital is installed.

\footnotetext{
${ }^{4}$ Consumers for which the marginal utility of consumption is convex, instead of linear, as is the case with the constant relative risk aversion utility function.
} 
Consumption

Real Disposable Income

Wealth

Interest rates

Confidence

Investment

Output

Financial and financing conditions

Spare capacity

Confidence and Uncertainty

Exports

World demand addressed to country

Relative export prices

Source: The Authors.
Real disposable income is the basic factor which determines households' propensity to consume. The link between consumption and income tends to be weaker the lower the incidence of liquidity contraints amongst households and the stronger the preference for precautionary savings (due to, e.g., inadequate insurance provided by social benefits or agents' low confidence about the future)

An increase in both financial (stocks, bonds, money) and real (typically housing) wealth motivates the household sector to increase consumption and decrease savings for any given level of income. Similarly, highly leveraged households facing financial restrains (e.g. lack of home equity that they can tap into to support their spending, difficulties refinancing into lower-rate loans etc.) will cut down on consumption expenditure

Through substitution effects, higher interest rates discourage borrowing to finance durable consumption goods and increases the return on savings, thereby reducing consumption. Through income effects, higher interest rates increase (reduce) income and consumption for creditors (debtors). The impact of interest changes on consumption ultimately depends on extent of leverage in the economy

An increase in consumer confidence about the state of the economy increases consumption and, as long as this extra spending does not come from additional income, it reduces savings. In many economies, consumers' confidence is heavily dependent on the evolution of unemployment

A standard accelerator view of investment suggests that investment outlays depend on expected output A range of financial and financing conditions can influence investment spending: (i) low corporate profits can inhibit investment plans insofar as external finance is more difficult to access (or is more expensive) than internal funds; (ii) highly indebted firms (or firms with low levels of equity in proportion of total liabilities) may defer investment as a means of adjusting the balance sheet to conserve cash and reduce debt ; (iii) a high real cost of capital may reduce investment in order to align the rate of return on investment to the cost of capital (neoclassical model); and (iv) credit rationing by banks can act as an impediment to investment

Spare capacity weighs on the level of investment and vice-versa, tight capital utilization signals constraints in the use of capital and spurs investment

Low confidence and elevated uncertainty increases the option value of deferring investment, since it is difficult to reverse investment once new capital is installed

Export performance improves with better demand prospects from the rest of the world The higher the price competitiveness of the exporter, the better export performance

\section{B. Data and Measurement Issues}

All series are taken directly from data sources, except the real cost of capital and the uncertainty indicator which are constructed for the purpose of the regressions. Private consumption, non-residential business investment, exports, nominal disposable income, net financial assets, households' indebtedness, non-residential business investment, the value added of the private sector, and consumption and investment deflators come from National Accounts (NA), as do profit margins (which we calculate as the share of gross operating surplus and mixed income in gross value added) and the equity to total liabilities ratio (which is computed from the corresponding stocks allocated to NFCs by the NA financial balance sheet system). Capacity utilization is taken from the National quarterly business survey and the unemployment rate comes from the Labor Force Survey (ILO concept). Interest rates for different maturities in the consumption equation are taken from the financial statistics of the respective national central bank. The financial constraints variable is from the European Commission Business and Consumer Survey (percent of respondents listing financial constraints as the factor limiting production). Real housing prices (proxy for real wealth) are taken for all three countries from the $2013 \mathrm{KBC}$ bank report. Potential export markets 
(weighted average of trading partners' imports based on the geographical orientation of the country's exports) are taken from Haver.

The real cost of capital is computed as the weighted cost of different sources of financing (net of the depreciation rate) adjusted for the relative price of investment goods:

$$
r_{k, t}=\left(r_{t}-\pi_{t}+\delta\right) * \frac{P_{I, t}}{P_{V A, t}}
$$

where $t$ denotes quarters, $r_{k}$ is the real cost of capital, $\pi$ is the private value added deflator inflation, $\frac{P_{I}}{P_{V A}}$ is the investment goods deflator relative to the private value added deflator, and $r$ is the weighted nominal cost of short- and long-term debt and equity. Equation (3) follows from neo-classical theory (Jorgenson, 1971) and postulates that, in equilibrium, companies invest up to the point where the return on capital equals the cost of financing it. The cost of equity is calculated as follows:

$$
r_{s, t}=100 *\left(\frac{D_{t+1}}{E_{t}}+\frac{D_{t+1}-D_{t}}{D_{t}}\right)
$$

where $r_{s}$ is the cost of equity, $D$ is total National Accounts dividend payments, and $E$ is total National Accounts shares and other equity.

The indicators measuring households' and firms' confidence and uncertainty about future economic conditions are constructed on the responses to the forward-looking question in the European Commission Business and Consumer Surveys, specifically "how do you expect your production to develop over the next three months?" and "how do you expect the financial position of your household to change over the next 12 months?". Confidence measures the average expectations about future economic conditions, thus are expressed as the balance of survey responses. ${ }^{5}$. Uncertainty measures the divergence in firms' views about the economic outlook, thus we compute it as the dispersion in survey responses. The basic idea is that a divergence of economic agents' expectations about the future should be a sign of higher uncertainty in the economy. To measure this divergence, we follow Balta and others (2012) and use the Theil's formula:

$$
\text { Uncertainty }=-\frac{1}{n} * \sum_{i=1 \text { to } n} \alpha_{i} * \log \left(\alpha_{i}\right)
$$

where log denotes the natural logarithm, $\alpha_{i}$ is the share of respondents choosing each type of reponse, and $n$ is the number of response categories for each of the forward-looking questions, i.e. 3 (increase, remain unchanged, decrease) for the question from the industry

\footnotetext{
${ }^{5}$ Answers obtained from the surveys are aggregated in the form of "balances". Balances are constructed as the difference between the percentages of respondents giving positive and negative replies and are subsequently seasonally adjusted.
} 
survey and 6 (get a lot better, get a little better, stay the same, get a little worse, get a lot worse, don't know) for the question from the consumer survey. The uncertainty index so computed ranges between 0 (respondents fully agree on economic prospects, whether gloomy or bright) and $0.3 / 0.4^{6}$ (greatest divergence in perceptions about the future across respondents). These indexes are normalized for the purpose of our regressions. The uncertainty indicators are distinct from the standard confidence indicators, which measure average expectations about the future economic conditions, and therefore do not convey information on the dispersion of responses.

For Germany and France, we also use the economic policy uncertainty indicator ${ }^{7}$ (Bloom, 2009), an index constructed from newspaper coverage, and which contains a mix of policyinduced confidence and uncertainty.

\section{RESUlTS}

Both long-term and dynamic equations are estimated for private consumption, nonresidential business investment, and exports. Dynamic equations are estimated in two steps, with and without confidence and uncertainty indicators. As a rule, an explanatory variable appears into the corresponding equation only if its coefficient is statistically significant at a 10 percent level. The estimated relationships generally support the priors laid down in Table 1. Demand developments in these countries are therefore driven by common, wellestablished determinants, yet country-specific factors also matter in some cases (investment dynamics in Germany and Belgium; exports performance in France and Germany). Shortterm dynamics suggests some role for confidence and uncertainty in explaining temporary deviations of demand variables from long-term fundamentals.

\section{A. Private Consumption}

Recent developments in consumption have essentially been consistent with past trends. There is no discernible break in the link of consumption and fundamentals over the period of analysis, including over 2008-13. Technically, the co-integration is validated by the EngleGranger test for each of the long-term equations. The stability of the income elasticity coefficient throughout time implies the stability of the saving rates in all three countries over the past three decades, despite the increase in wealth. This is consistent with the evidence by Bakker and Felman (2014), who find a weak relationship between wealth and savings in France and Germany, unlike the situation in the US, the UK, or the Baltics. ${ }^{8}$

\footnotetext{
${ }^{6} 0.3$ for the question addressed to households and 0.4 for the question addressed to firms.

${ }^{7}$ Methodology and data available at http://www.policyuncertainty.com/europe monthly.html.

8 Inequality patterns could explain these divergences. The rich are found to be more sensitive to changes in wealth than the middle class: they are more willing to borrow and spend when they have capital gains, because they can better cushion wealth losses. Savings will therefore tend to be more volatile in economies dominated by the rich, while consumption will tend to be more stable in countries where income is more evenly distributed, such as Germany and France.
}

(continued) 
Table 2. Estimation Results for Private Consumption

\begin{tabular}{|c|c|c|c|c|c|c|}
\hline \multirow{2}{*}{$\begin{array}{l}\text { Variable } \\
\text { Long-term equation (FMOLS) }\end{array}$} & \multicolumn{2}{|c|}{ France } & \multicolumn{2}{|c|}{ Germany } & \multicolumn{2}{|c|}{ Belgium } \\
\hline & & & & & & \\
\hline log (Real disposable income) & 0.859 & $(40.44)^{* * *}$ & 1.056 & $(37.49) * * *$ & 0.873 & $(44.16) * * *$ \\
\hline $\log ($ Real financial wealth $(-1)$ ) & 0.086 & $(5.54)^{* * *}$ & - & - & 0.042 & $(2.09)^{* *}$ \\
\hline $\log ($ Real housing prices $(-1))$ & & & -0.087 & $(2.44) * *$ & & \\
\hline Unemployment rate $(-2)$ & - & - & -0.003 & $(5.32) * * *$ & - & - \\
\hline Constant & - & - & - & - & 0.791 & $(2.42) * \star$ \\
\hline Adjusted $R$-squared & & 0.99 & & 0.99 & & 0.98 \\
\hline Engle-Granger tau-statistic & & $-5.98 \stackrel{000}{0}$ & & 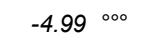 & & $-5.13^{000}$ \\
\hline Total observations & & 70 & & 72 & & 72 \\
\hline \multicolumn{7}{|l|}{ Dynamic equation (OLS) } \\
\hline$\Delta \log ($ Real private consumption $(-1))$ & 0.293 & $(3.58) * *$ & - & - & 0.560 & $(6.24)^{* \star}$ \\
\hline$\Delta \log ($ Real disposable income) & 0.144 & $(2.40) * *$ & 0.517 & $(8.13) * * *$ & 0.069 & $(1.96) *$ \\
\hline$\Delta \log ($ Real financial wealth $(-1))$ & 0.070 & $(4.99)^{* * *}$ & - & - & - & - \\
\hline$\Delta \log ($ Real housing prices $(-1))$ & 0.042 & $(2.13) * *$ & -0.096 & $(1.82) *$ & -0.045 & $(2.39) * *$ \\
\hline$\Delta$ Unemployment rate $(-2)$ & - & - & -0.006 & $(3.55) * * *$ & -0.003 & $(2.73)^{* \star *}$ \\
\hline Long-term equation residuals $(-1)$ & -0.329 & $(4.55)^{* * *}$ & -0.171 & $(2.11) * *$ & -0.178 & $(5.15)^{* * *}$ \\
\hline Constant & 0.001 & $(2.29)$ ** & 0.001 & $(3.28) * * *$ & 0.001 & $(2.82)^{* \star *}$ \\
\hline Adjusted R-squared & & 0.55 & & 0.70 & & 0.53 \\
\hline Breusch-Godfrey $L M(1)$ & & $1.27^{\wedge}$ & & $0.53^{\wedge}$ & & $0.14 \wedge$ \\
\hline Total observations & & 67 & & 71 & & 71 \\
\hline
\end{tabular}

There is evidence of a strong link between consumption and real disposable income for the three countries (Table 2). The income elasticity is slightly above one in Germany and stands at about 0.85 in France and Belgium9. The faster growth in private consumption in France and Belgium relative to Germany owes to greater dynamism in disposable income 10 in these two countries (the income elasticity is actually higher for Germany). Two distinct subperiods can, however, be identified within the sample: 1998-2007, where the contribution of real disposable income to consumption growth in France and Belgium (2.1 ppts. and 1.6 ppts. respectively) largely outperformed that in Germany ( 0.9 ppts.); and 2008-12, where the

\footnotetext{
${ }^{9}$ In order to obtain a co-integrated relationship, in the case of Belgium property income has been excluded from disposable income, following De Ketelbutter and others (2014). The income elasticity for Belgium is thus not fully comparable with those obtained for France and Germany.

${ }^{10}$ In the case of Belgium, disposable income excludes property income in the computation of its contribution to private consumption.
} 
contribution of real disposable income to consumption growth in France (at about 0.4 ppts.) fell behind that in Germany and Belgium (0.8 and 1.0, respectively).

While we found no evidence that financial wealth effects matter for consumption in Germany, it only played a role pre-crisis in France, where it contributed to lift consumption growth by 0.4 per year, and had just a marginal effect in Belgium. This is consistent with previous findings for France (Arrondel and others, 2011, and Chauvin and Damette, 2010), Belgium (De Ketelbutter and others, 2014), and Germany (Altissimo and others, 2005), all pointing to weak, if any, wealth effects for consumption. Real estate wealth (proxied by the evolution of housing prices) plays a role in none of the countries: either it is non-significant (France, Belgium) or is negatively signed, pointing to income, rather than wealth, effects (Germany). ${ }^{11}$

In the case of Germany, a decline in the unemployment rate of one percentage point is found to improve consumption by about 0.3 percent. Noteworthy, the unemployment rate and consumer confidence proved simultaneously non-significant in a regression augmented with the latter (not shown). This may be indication that the unemployment rate incorporates confidence effects. Similarly, the stronger labor market performance in Germany relative to France and Belgium could have driven the swifter recovery in German consumers' confidence as of early 2009. Safe

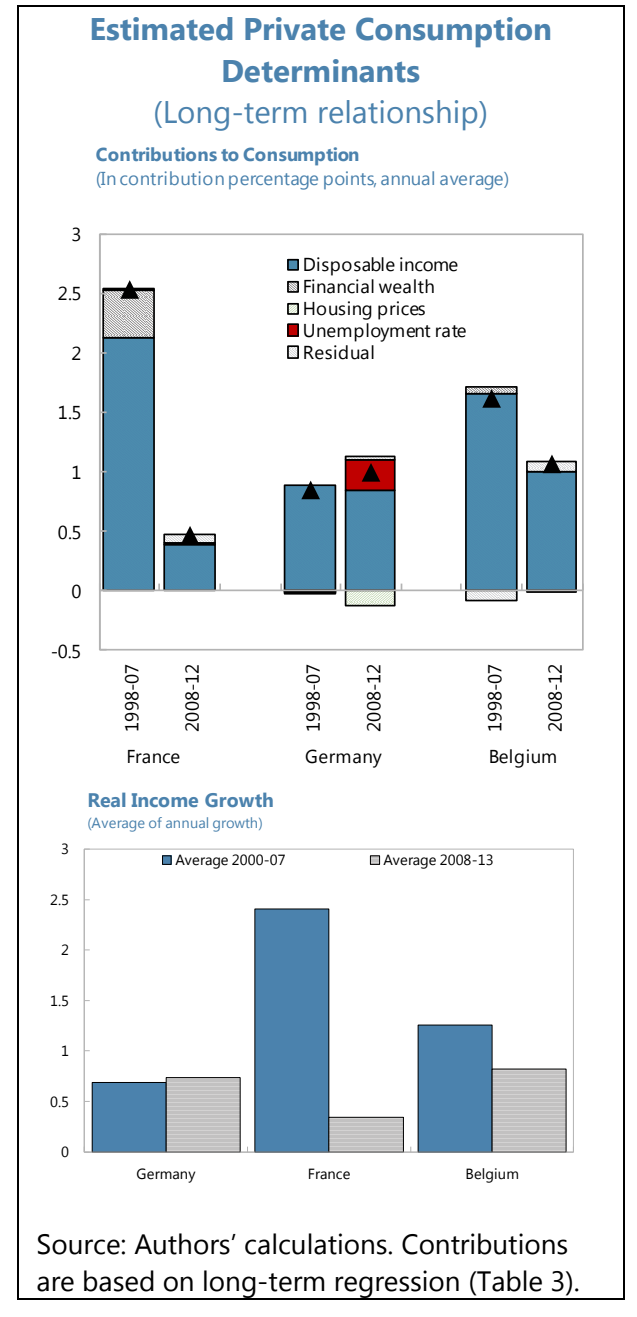
heaven effects and the perception of Germany as an anchor to stability in the early stages of the crisis may also have provided an additional boost to German consumers' confidence. Real interest rates using different maturities and deflators were tested but appeared not to be significant in a robust way neither in the long-term regression nor in the dynamic equation. ${ }^{12}$ Although the relationship between real private consumption and disposable income has been tight over the sample period, developments in consumption and income growth diverged at times, reflecting fluctuations in the savings rate. Contributions to consumption growth as

\footnotetext{
${ }^{11}$ Low levels of housing ownership in Germany may explain why rising housing prices reduce consumption. Higher house prices may also imply a larger mortgage debt service, leaving less room for consumption.

${ }^{12}$ Note that due to data limitations, the ratio of household debt to disposable income could only be tested on a shorter sample. Its coefficient appeared as significantly positive in the case of Germany and Belgium, showing some evidence of leveraging.
} 
estimated by the dynamic equation shed light on the factors underlying the gap between the two variables. To illustrate this, we report contributions from the dynamic equation augmented with confidence and uncertainty indicators (Table 3). This specification for the dynamic equation improves the regression fit relative to the alternative where those indicators are omitted (Table 2). Focusing on France and Germany ${ }^{13}$, two periods can be distinguished in assessing the evolution of consumption and disposable income:

In the pre-crisis period, private consumption was considerably less volatile than income in France. These developments suggest that households attempted to smooth consumption over time in the face of variations in income by borrowing/lending. In Germany, household income displayed higher volatility than in France, and was tightly correlated with private consumption. As a result, Germany's private consumption fluctuated relatively more than in France during this period.

Following the failure of Lehman and as the Euro area sovereign crisis intensified in 2011, consumption became more volatile than income in the two countries as financial market disruptions likely made the borrowing and/or lending required to smooth consumption more difficult. Low confidence also dragged down French private consumption considerably throughout this period. Its negative contribution to German consumption was more muted over 2008-09, thereafter turning into positive territory. Uncertainty only mattered for France, pulling down consumption late in 2008 and again by end-2010. More positively, vigorous income growth in Germany and financial wealth effects in France cushioned the negative impact of fiscal austerity on household income and helped smooth consumption.

A few more insights from the role played by confidence and uncertainty indicators in explaining short-term dynamics include: (i) for France the coefficients of the consumer confidence and policy uncertainty indicator are not simultaneously significant (policy uncertainty may actually capture confidence effects, if partially); (ii) the size of confidence and uncertainty indicators (as computed from the EC Business and Consumer Survey) is comparable to the ones obtained by Balta and others (2012) for a panel of nine euro-area countries; (iii) the introduction of confidence and uncertainty indicators in the dynamic equation reduces the short-term elasticity to disposable income for France but leaves it unchanged for Germany; and (iv) for Germany, uncertainty does seem to matter while the introduction of consumer confidence turns the unemployment rate in the base model nonsignificant (i.e. unemployment rate seems to capture confidence effects in Germany).

\footnotetext{
${ }^{13}$ In the case of Belgium, confidence and uncertainty indicators are found to be non-significant.
} 
Table 3. Estimation Results for Private Consumption including Confidence and Uncertainty indicators

\begin{tabular}{|c|c|c|c|c|c|c|}
\hline \multirow{2}{*}{$\begin{array}{l}\text { Variable } \\
\text { Dynamic equation (OLS) }\end{array}$} & \multicolumn{2}{|c|}{ France (variant 1) } & \multicolumn{2}{|c|}{ France (variant 2) } & \multicolumn{2}{|c|}{ Germany } \\
\hline & & & & & & \\
\hline$\Delta \log ($ Real private consumption $(-1))$ & 0.187 & $(2.04) * *$ & 0.251 & $(3.16) * * \star$ & - & - \\
\hline$\Delta \log$ (Real disposable income) & - & - & 0.125 & $(2.16) * \star$ & 0.526 & $(8.46)^{* * *}$ \\
\hline$\Delta \log ($ Real financial wealth $(-1))$ & 0.062 & $(4.51) * * *$ & 0.057 & $(4.17) * * \star$ & - & - \\
\hline$\Delta \log ($ Real housing prices $(-1))$ & - & - & - & - & -0.124 & $(2.32) * *$ \\
\hline$\Delta$ Unemployment rate $(-2)$ & - & - & - & - & - & - \\
\hline Long-term equation residuals $(-1)$ & -0.199 & $(3.10)^{* * *}$ & -0.288 & $(4.15)^{* \star *}$ & -0.303 & $(3.63)^{* * *}$ \\
\hline Consumer confidence (-1) 1 / & 0.0003 & $(3.42) * * \star$ & - & - & 0.0004 & $(3.99)^{* * *}$ \\
\hline$\Delta$ Consumer uncertainty $(-2) 1 /$ & -0.001 & $(1.77)^{*}$ & -0.001 & $(1.82)$ * & - & - \\
\hline Policy uncertainty & - & - & -0.003 & $(3.10) * * \star$ & - & - \\
\hline Constant & 0.004 & $(5.74) * * *$ & 0.005 & $(4.23) * * *$ & 0.003 & $(5.22)^{* \star *}$ \\
\hline Adjusted R-squared & & 0.57 & & 0.59 & & 0.71 \\
\hline Breusch-Godfrey $L M(1)$ & & $0.32 \wedge \wedge$ & & $0.43^{\wedge}$ & & $0.30^{\wedge}$ \\
\hline Total observations & & 67 & & 67 & & 71 \\
\hline
\end{tabular}

\section{B. Non-residential Business Investment}

Business investment dynamics during the crisis has been pinned down by conventional determinants (Table 4). A long-term relationship between investment and its fundamentals is confirmed for Belgium. If less obvious for France and Germany ${ }^{14}$, the residuals of the cointegration equation are reasonably stationary. The magnitude and statistical significance of the coefficient of the error-correction term in the dynamic equation ensures that the system is brought back to equilibrium within one to two years. As postulated by the accelerator model, business

Contributions to Investment (In contribution percentage points, annual average) investment behavior is largely driven by output developments. The long-term elasticity to private value added is very similar in all three countries and well above one. In the very long run, the investment to GDP ratio shows little or no trend. Consistent with this, the elasticity of investment to output estimated from long samples would converge to one. In the sample used here, the investment to GDP ratio shows a slight upward trend for the three countries considered; hence the estimated elasticity is higher than one. When the regression is extended to also include the price of investment goods relative to the private value added deflator, the restrictions for real

\footnotetext{
${ }^{14}$ For these two countries, the Engle-Granger test null hypothesis that the series are not co-integrated cannot be formally rejected at the usual significance levels.
} 
value added and the relative price of, respectively, 1 and -1 , are rejected. ${ }^{15}$

The estimates suggest an almost a one-to-one relationship between investment and firms' profit margins in France, but clearly lower for Germany (0.6) and even more for Belgium (0.2). While non-significant for Germany, both France and Belgium post high elasticities to the cost of capital ( -0.9 and -0.8 , respectively $)^{16}$. The ratio of equity liabilities to total liabilities is positively signed in the three countries, suggesting that elevated corporate leverage is associated with weak investment. A one-percent decrease in such ratio dampens investment by 0.2 in France and Germany, and up to 0.3 in Belgium.

As an alternative to the ratio of equity liabilities to total liabilities, we also tested the corporate debt to equity ratio. As expected we obtained a negative coefficient but results appeared to be less robust than with the ratio of equity liabilities to total liabilities. ${ }^{17} \mathrm{~A}$ variable capturing credit rationing (based on a question regarding financial constraints from the EC consumer and business survey) was also introduced in the equation but its coefficient was insignificant for all three countries.

In addition to common determinants, other country-specific factors dragged investment in both Belgium and Germany, as captured by the negative time trend in the co-integration equations. One factor behind sluggish capital formation in Germany is that corporations redirected investment from the domestic economy to international investment, off-shoring production and creating supply chains, particularly in low-cost Eastern Europe, following the eastward expansion of the European Union (IMF, 2013). For instance, in the case of the automotive industry, factories in Eastern Europe became a part of Germany-centered value chains (Iwulska, 2012). Industry offshoring, in particular to Central and Eastern European countries (Hertveldt and Michel, 2013), is likely to have also weighed on Belgian investment.

\footnotetext{
${ }^{15}$ By testing these restrictions we check whether the investment-to-value added ratio expressed in current prices is stationary.

${ }^{16}$ Lack of National Accounts data for the dividend payments of NFCs, the cost of capital used in the equation does not include the cost of equity for Belgium.

${ }^{17}$ This result may be explained by the fact that, due to data limitations, the estimation sample was significantly reduced.
} 
Table 4. Estimation Results for Non-residential Private Investment

\begin{tabular}{|c|c|c|c|c|c|c|}
\hline Variable & \multicolumn{2}{|c|}{ France } & \multicolumn{2}{|c|}{ Germany } & \multicolumn{2}{|c|}{ Belgium } \\
\hline \multicolumn{7}{|l|}{ Long-term equation (FMOLS) } \\
\hline log (Private value added) & 1.382 & $(27.33)^{* \star *}$ & 1.395 & $(5.60) * * *$ & 1.351 & $(9.98) * * *$ \\
\hline $\log (1+$ real cost of capital) & -0.915 & $(4.01) * * *$ & - & - & -0.794 & $(4.37)^{* * *}$ \\
\hline Iog (Equity liabilities/total liabilities)(-2) & 0.162 & $(4.19) * * *$ & 0.184 & $(3.07)^{* * *}$ & 0.268 & $(4.31)^{* * *}$ \\
\hline Iog (Gross operating surplus (-2)) & 0.983 & $(4.83) * * *$ & 0.612 & $(4.08)^{\star * *}$ & 0.220 & $(1.70) *$ \\
\hline Constant & -3.806 & $(15.21)^{* \star *}$ & -4.272 & $(3.05)^{* * *}$ & -6.281 & $(4.55)^{\star \star \star}$ \\
\hline Trend & - & - & -0.004 & $(4.19) * * *$ & -0.003 & $(5.31)^{* * *}$ \\
\hline Adjusted R-squared & & 0.98 & & 0.88 & & 0.97 \\
\hline Engle-Granger tau-statistic & & -3.97 & & -3.87 & & $-6.43^{\circ 00}$ \\
\hline Total observations & & 71 & & 72 & & 71 \\
\hline \multicolumn{7}{|l|}{ Dynamic equation (OLS) } \\
\hline$\Delta \log ($ Business investment $(-1))$ & 0.553 & $(7.86) * * *$ & - & - & - & - \\
\hline$\Delta \log$ (Private value added) & 1.494 & $(8.48) * * *$ & 1.543 & $(7.01)^{* * *}$ & 1.066 & $(3.47)^{* * *}$ \\
\hline$\Delta \log ($ Private value added $(-1))$ & -0.851 & $(3.68)^{* * *}$ & - & - & - & - \\
\hline$\Delta \log ($ Private value added $(-2))$ & - & - & - & - & 1.034 & $(3.51)^{* * *}$ \\
\hline$\Delta \log ($ Gross operating surplus $(-2))$ & 0.243 & $(2.46) * *$ & - & - & - & - \\
\hline$\Delta \log$ (Capacity utilisation rate) & 0.267 & $(5.20) * * *$ & 0.283 & $(2.51)^{* *}$ & - & - \\
\hline Long-term equation residuals $(-1)$ & -0.281 & $(7.05) * * *$ & -0.306 & $(4.78) * * *$ & -0.595 & $(5.54)^{\star * *}$ \\
\hline Constant & - & - & -0.004 & $(1.96)$ * & -0.005 & $(1.93) *$ \\
\hline Adjusted R-squared & & 0.84 & & 0.72 & & 0.53 \\
\hline Breusch-Godfrey LM(1) & & $0.00^{\wedge \wedge \wedge}$ & & $0.64^{\wedge}$ & & $0.88^{\wedge}$ \\
\hline Total observations & & 70 & & 69 & & 70 \\
\hline
\end{tabular}

Although the relationship between business investment and private value added has been tight over the sample period, developments in these two variables diverged at times, reflecting fluctuations in the investment rate. Contributions to investment growth as estimated by the dynamic equation shed light on the factors underlying the gap between the two variables. To illustrate this, we report contributions from the dynamic equation for France, and from the dynamic equation augmented with confidence and uncertainty indicators for Germany and Belgium (Table 5), as this variant improves the fit upon a regression where those indicators are omitted (Table 4). For France and Germany, highfrequency movements in business investment have been considerably more volatile than output developments, especially during the crisis. Changes in capacity utilization explain a large part of the decoupling of investment from output since 2008, coupled with weak confidence in Germany after the Lehman failure, and an unexplained component in France. 
The role played by confidence and uncertainty indicators in explaining short-term dynamics differs across countries. For Belgium, both confidence and changes in uncertainty are significant and improve the regression fit, with the two indicators contributing to the drop in the investment rate over 2009-10. For Germany, only business confidence is significant, improving the adjusted R-squared and contributing to the investment recovery in 2011 . For France, the base model already provided a very good statistical fit and none of the two indicators proved to be statistically significant.

Table 5. Estimation Results for Non-residential Private Investment including Confidence and Uncertainty indicators

\begin{tabular}{|c|c|c|c|c|}
\hline Variable & \multicolumn{2}{|c|}{ Germany } & \multicolumn{2}{|c|}{ Belgium } \\
\hline \multicolumn{5}{|l|}{ Dynamic equation (OLS) } \\
\hline$\Delta \log$ (Private value added) & 1.548 & $(7.27)^{\star \star \star}$ & 1.076 & $(4.53) * * \star$ \\
\hline$\Delta \log$ (Capacity utilisation rate) & 0.261 & $(2.39)^{* *}$ & - & - \\
\hline Long-term equation residuals $(-1)$ & -0.287 & $(4.59) * \star \star$ & -0.575 & $(5.76)^{* * *}$ \\
\hline Business confidence $(-2) 1 /$ & 0.0003 & $(2.30)^{* *}$ & 0.0007 & $(2.80)^{* * *}$ \\
\hline$\Delta$ Business uncertainty $(-2) 1 /$ & - & - & -0.008 & $(3.84)^{* * *}$ \\
\hline Constant & 0.004 & $(2.42) * \star$ & - & - \\
\hline Adjusted R-squared & & 0.74 & & 0.61 \\
\hline Breusch-Godfrey $L M(1)$ & & 3.02 & & $0.10^{\wedge \wedge}$ \\
\hline Total observations & & 69 & & 70 \\
\hline
\end{tabular}

\section{Exports}

As with private consumption and business investment, the econometric analysis suggests that exports developments during the crisis have been anchored in conventional determinants, namely world demand and export price competitiveness (Table 6).

There is evidence that external demand is the main driver of export performance for these economies, contributing the most to overall export growth in France, Belgium, and Germany over 1997-2012. The euro area crisis had a negative impact on these countries, as demand from euro area trading partners declined, especially during the early phase of the crisis in 2008-09. The analysis also shows that adjustments in relative export deflators also mattered for the three countries, with French exports benefitting the most from a decline of the exports deflator relative to its trading partners. 
Table 6. Estimation Results for Exports of Goods and Services

\begin{tabular}{|c|c|c|c|c|c|c|}
\hline Variable & \multicolumn{2}{|c|}{ France } & \multicolumn{2}{|c|}{ Germany } & \multicolumn{2}{|c|}{ Belgium } \\
\hline \multicolumn{7}{|l|}{ Long-term equation (FMOLS) } \\
\hline log (Potential export markets) & 0.851 & $(16.31)^{* \star *}$ & 0.754 & $(19.86)^{* * *}$ & 0.699 & $(89.25)^{* \star *}$ \\
\hline Iog (Export prices relative to competitors) & -0.782 & $(11.95)^{* * *}$ & -0.247 & $(4.83) * * *$ & -0.341 & $(5.79)^{* * *}$ \\
\hline Constant & 1.228 & $(6.09) * * *$ & 1.916 & $(13.16)^{* * *}$ & 10.687 & $(1682) * \star *$ \\
\hline Trend & -0.006 & $(7.69) * * *$ & 0.003 & $(4.46) * * *$ & - & - \\
\hline Adjusted R-squared & & 0.98 & & 0.99 & & 0.99 \\
\hline Engle-Granger tau-statistic & & -5.21000 & & -5.26 & & $-5.70^{\circ 00}$ \\
\hline Total observations & & 74 & & 74 & & 74 \\
\hline \multicolumn{7}{|l|}{ Dynamic equation (OLS) } \\
\hline$\Delta \log ($ Exports $(-1))$ & 0.246 & $(3.50) * *$ & 0.176 & $(2.23)^{* *}$ & 0.188 & $(2.53) * *$ \\
\hline$\Delta \log$ (Potential export markets) & 0.465 & $(8.75) * * *$ & 0.207 & $(2.59) * *$ & 0.535 & $(7.62)^{* \star \star}$ \\
\hline$\Delta \log$ (Export prices relative to competitors) & -0.133 & $(3.22) * * *$ & -0.167 & $(3.51) * * *$ & -0.163 & $(1.96)^{*}$ \\
\hline Long-term equation residuals $(-1)$ & -0.221 & $(4.03) * * *$ & -0.458 & $(6.07) * * *$ & -0.430 & $(5.18)^{* \star *}$ \\
\hline Constant & - & - & 0.010 & $(4.43) * * *$ & - & - \\
\hline Adjusted R-squared & & 0.69 & & 0.75 & & 0.82 \\
\hline Breusch-Godfrey $L M(1)$ & & $1.97^{\wedge}$ & & $0.38^{\wedge \wedge}$ & & $0.26 \wedge \wedge$ \\
\hline Total observations & & 71 & & 71 & & 72 \\
\hline
\end{tabular}

In addition to common determinants, other country-specific drivers were at play. These factors weighed on exports in France and provided an additional boost to German exports, as captured by the trend components in the respective co-integration equations. One possible explanation for the differing trend components in these two countries relates to global value chains (GVCs), which has transformed patterns of international trade. ${ }^{18}$ As Germany serves both intermediate and final demand from China (German exports to China rank, alongside France, Italy and the UK, as the next important export destination after the US), it would derive greater benefit from extra-area trade than other most Euro area members. Still, France export performance appears weak even when correcting for the fact that it is less integrated in the GVCs (Hallaert, 2014). This suggests other factors may be at play. Shift-share analysis techniques (Gaulier and others, 2013) confirm factors other than product specialization and destination effects, such as innovation, customer service, etc. (so-called "exporter effect"), has dragged exports in France. Although Belgian exports exhibit no negative trend, it has the

\footnotetext{
${ }^{18}$ Trade linkages through GVCs challenge traditional measures of trade, which are computed in gross terms: they capture the total value of shipments into and out of the country. Yet, what matters for the contribution that trade makes to GDP is value added in that trade. This strips out the import content of gross exports.
} 
lowest elasticity to potential export markets, indicating that the above-mentioned competitiveness issues would also apply.

In all, exports data over the sample period suggest that the decoupling of France from Germany pre-dates the crisis. The exports rebound as of late 2008 would have allowed the two countries to return to past trends (steeper for Germany). This meant a stronger rebound for Germany relative to France, rooted in factors other than geographical specialization and price competitiveness (already captured by the export markets and relative price exports components in the regression).

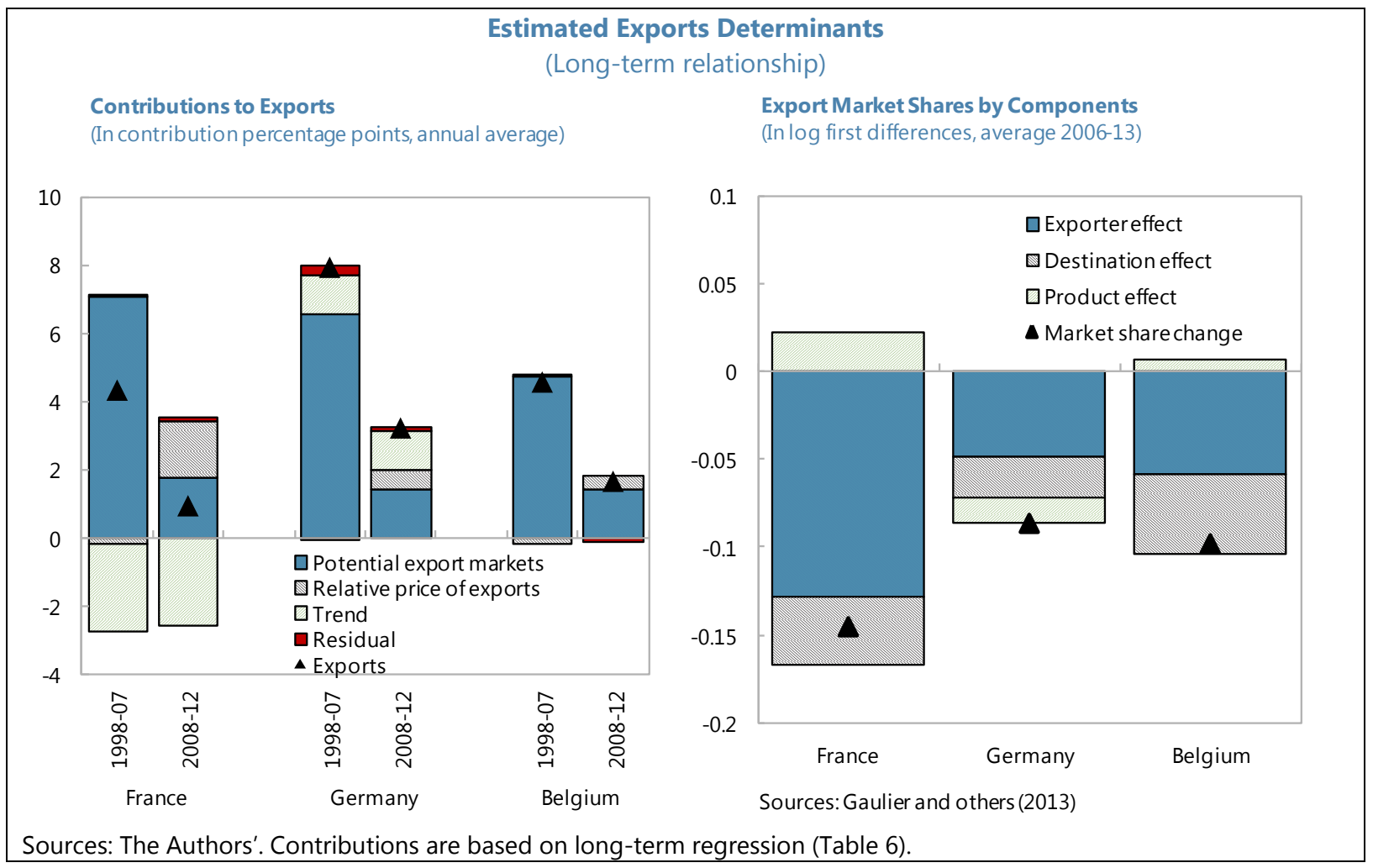

\section{Demand Patterns in France, Germany, and Belgium: Are They Different?}

The evidence provided so far raises the question as to whether demand developments observed in the three countries merely reflect divergent patterns in the underlying fundamentals or whether they are indicative of deeper structural differences (i.e. distinct elasticities). To address this question, we check on the equality of the coefficients from the consumption, investment, and export long-term equations by means of z-test, which allows for pair-wise comparison of coefficients from independent equations (Table 7). We find that all common coefficients in the long-term regressions are not statistically different, with the notable exceptions of the consumption elasticity to disposable income, which is significantly higher for Germany than for the two other countries; the investment elasticity to profit margins, which is significantly lower for Belgium than for France and Germany; and the 
exports elasticity to export relative prices, which is significantly higher (in absolute value) for France relative to Germany and Belgium.

Table 7. Equality test of regression coefficients

\begin{tabular}{|c|c|c|c|c|c|c|c|c|c|}
\hline \multirow[b]{4}{*}{ Private consumption } & \multicolumn{6}{|c|}{ Long-term Regression Coefficients } & \multirow{3}{*}{\multicolumn{3}{|c|}{$\begin{array}{c}\text { Z-test } \\
\text { Null hypothesis }\end{array}$}} \\
\hline & \multicolumn{2}{|c|}{$\mathrm{FR}$} & \multicolumn{2}{|c|}{$\mathrm{DE}$} & \multicolumn{2}{|c|}{$\mathrm{BE}$} & & & \\
\hline & \multirow[t]{2}{*}{ Coefficient } & \multirow[t]{2}{*}{ Std. Error } & \multirow[t]{2}{*}{ Coefficient } & \multirow[t]{2}{*}{ Std. Error } & \multirow[t]{2}{*}{ Coefficient } & \multirow[t]{2}{*}{ Std. Error } & & & \\
\hline & & & & & & & $\mathrm{FR}=\mathrm{DE}$ & $\mathrm{FR}=\mathrm{BE}$ & $\mathrm{DE}=\mathrm{BE}$ \\
\hline Real disposable income & 0.86 & 0.02 & 1.06 & 0.03 & 0.87 & 0.02 & 5.60 & 0.51 & 5.30 \\
\hline Real financial wealth & 0.09 & 0.02 & & & 0.04 & 0.02 & & 1.77 & \\
\hline \multicolumn{10}{|l|}{ Non-residential private investment } \\
\hline Private value added & 1.38 & 0.05 & 1.40 & 0.25 & 1.35 & 0.14 & 0.05 & 0.21 & 0.16 \\
\hline Real cost of capital & -0.91 & 0.23 & & & -0.79 & 0.18 & & 0.42 & \\
\hline Equity liabilities/total liabilities & 0.16 & 0.04 & 0.18 & 0.06 & 0.27 & 0.06 & 0.30 & 1.45 & 0.98 \\
\hline Gross operating surplus & 0.98 & 0.20 & 0.61 & 0.15 & 0.22 & 0.13 & 1.47 & 3.16 & 1.98 \\
\hline Trend & & & 0.00 & 0.00 & 0.00 & 0.00 & & & 1.03 \\
\hline \multicolumn{10}{|l|}{ Exports of goods and services } \\
\hline Potential export markets & 0.85 & 0.05 & 0.75 & 0.04 & 0.70 & 0.01 & 1.50 & 2.89 & 1.43 \\
\hline Export prices relative to competitors & -0.78 & 0.07 & -0.25 & 0.05 & -0.34 & 0.06 & 6.45 & 5.00 & 1.21 \\
\hline
\end{tabular}

\section{CONCluding Remarks}

Developments in domestic and external demand are key to growth and adjustment. The Euro area currently faces the double challenge of correcting intra-Euro area imbalances while reviving area-wide growth. The need to manage potential shorter-term tensions between adjustment and growth highlights the importance of the evolution of domestic demand in the core.

Having been weak prior to the crisis, German household disposable income is now the strongest amongst the large Euro area economies. The prospects for future household income growth look promising, given accelerating wage growth and supportive fiscal dynamics. With the economy now running at close to full capacity and German unemployment standing at 5.1 percent, strong employment growth and rising wages should continue to boost labor income in the coming quarters, while healthy public finances suggest that the drag on household income coming from taxes should diminish over time. This should support private consumption in Germany and contribute to stronger euro-area growth.

The outlook for household income appears more mixed for France and Belgium, where income growth has held up well to date, though largely owing to resilient wage growth which is likely to prove untenable over time, as there is still need for fiscal and external adjustment. Indeed, despite the recent improvement in the external position, France and Belgium still require some improvements in both cost and non-cost competitiveness to achieve external sustainability. To facilitate the adjustment, structural reforms remain a better approach than outright declines in wages and prices. Efforts to switch production from domestic sectors in France and Belgium (government and sheltered services) to export-oriented sectors would help. 


\section{REFERENCES}

Altissimo, F., E. Georgiou, T. Sastre, M.T. Valderrama, G. Sterne, M. Stocker, M. Weth, K. Whelan, and A. Willman, 2005, "Wealth and Asset Price Effects on Economic Activity", Occasional Paper Series, No. 29, European Central Bank.

Arrondel, L., F. Savignac, and K. Tracol, 2011, "Wealth effects on consumption plans: French households in the crisis," Document de travail No. 344. September 2011.

Balta, N., I. Valdés, and E. Ruscher, 2013, "Assessing the Impact of Uncertainty on Consumption and Investment," Quarterly Report on the Euro Area, Vol. 12 N.2, 2013.

Bloom, N., 2009, “The Impact of Uncertainty Shocks," Econometrica, Vol. 77, No. 3, pages 62385 .

Bakker, B.B. and J. Felman, 2014, "Boom-Busts and the Rich: How Have Wealth and Inequality Influenced Business Cycles?," IMF Working Papers, forthcoming.

Bernanke, B. S.. 1983, "Irreversibility, Uncertainty, and Cyclical Investment," Quarterly Journal of Economics, Vol. 97, No. 1, February 1983, pages 85-106.

Chauvin, V., and O. Damette, 2010, "Wealth Effects: the French case," January 2010, Document de travail No. 276.

De Ketelbutter B., L. Dobbelaere, I. Lebrun, and F. Vanhorebeek, 2014, "A new version of MODTRIM II. An overview of the model for short-term forecasts", Federal Planning Bureau, Working Paper 4-14, June 2014.

Dustmann, C. and others, 2014, "From Sick Man of Europe to Economic Superstar: Germany's Resurgent Economy," The Journal of Economic Perspectives 28.1 (2014): 167-188.

Eisner, R, and R.H. Strotz, 1963, "Determinants of Business Investment," Impacts of Monetary Policy. Englewood Cliffs, NJ: Prentice-Hall.

Friedman, M., 1957, “The Permanent Income Hypothesis," NBER Chapters, in: A Theory of the Consumption Function, pages 20-37, National Bureau of Economic Research, Inc.

Gaulier, G., G. Santoni, D. Taglioni, and S. Zignago, 2013, "Market Shares in the Wake of the Global Crisis: The Quarterly Export Competitiveness Database", Documents de travail, Banque de France, 472.

Hallaert, JJ, 2014, "France in the Global Value Chains: Revisiting the Competitiveness Loss," 2014 France Selected Issues, Country Report No. 14/183.

Hall, R.E., 1978, "Stochastic implications of the life cycle-permanent income hypothesis," Journal of Political Economy 86 (6), pages 971-87. 
Hertveldt, B. and B. Michel, 2013, "Offshoring and the Skill Structure of Labour Demand in Belgium”, De Economist 161, pages 399-420.

IMF, 2013, "The German-Central European Supply Chain Cluster Report," IMF Country Report No. $13 / 263$.

Iwulska, A., 2012, "Country benchmarks" prepared for the World Bank report "Golden Growth: Restoring the lustre of the European economic model".

Jorgenson, D., 1971, "Econometric Studies of Investment Behaviour: A Survey," Journal of Economic Literature, 9 (4), December 1111- 47.

Keynes, John Maynard, 1936, “The General Theory of Employment, Interest and Money, London: Macmillan, reprinted 2007.

Kao, C., and Chiang, M.H, 2000, "On the estimation and inference of a co-integrated regression in panel data," Advances in Econometrics, 15, 179-222.

Krebs, T., and M. Scheffel, 2013, "Macroeconomic Evaluation of Labor Market Reform in Germany,” IMF Economic Review 61.4 (2013), pages 664-701.

Leland, H. 1968, "Saving and Uncertainty: The Precautionary Demand for Saving" The Quarterly Journal of Economics 2, pages 465-473.

Mark, Nelson C. and Donggyu Sul, 2003, "Cointegration Vector Estimation by Panel DOLS and Long-run Money Demand," Oxford Bulletin of Economics and Statistics, Department of Economics, University of Oxford, vol. 65(5), pages 655-680, December.

Modigliani, F., and R. Brumberg, 1954, "Utility Analysis and the Consumption Function," In Post-Keynesian Economics. Edited by K. Kurihara. New Brunswick, N.J.: Rutgers University Press, 1954, pages 338-436.

Pedroni, P., 2000, "Fully Modified OLS for Heterogeneous Cointegrated Panels," Advances in Econometrics, Vol. 15, pages 93-130.

Pedroni, P., 2001, "Purchasing Power Parity Tests In Cointegrated Panels," The Review of Economics and Statistics, MIT Press, vol. 83(4), pages 727-731, November.

Phillips, Peter C. B. and Hyungsik R. Moon, 1999, "Linear Regression Limit Theory for Nonstationary Panel Data," Econometrica, Econometric Society, vol. 67(5), pages 1057-1112, September.

Pindyck, R. S, 1991, "Irreversibility, Uncertainty, and Investment," Journal of Economic Literature, American Economic Association, vol. 29(3), pages 1110-48, September.

Romer, David, 2011, “Advanced Macroeconomics”, McGraw-Hill, $4^{\text {th }}$ edition. 